\title{
Cyber entrepreneurial venture: Case studies on Phenomenon of Venture Creation
}

\author{
Supreet Juneja Wahee ${ }^{1}$, Dr. Broto Bhardwaj ${ }^{2}$, A.R Deshmukh ${ }^{3}$ \\ ${ }^{1}$ Asst. Professor,Bharati Vidyapeeth Institute of Management \& Research, New Delhi, India \\ supreetwahee@gmail.com ${ }^{1}$ \\ ${ }^{2}$ Head, Entrepreneurship \& Research,Bharati Vidyapeeth Institute of Management \& Research, New \\ Delhi, India \\ brotobhardwaj@gmail.com² \\ ${ }^{3}$ Programme Director SDE,Bharati Vidyapeeth Institute of Management \& Research, New Delhi, India \\ amarsuja@yahoo.com
}

\begin{abstract}
Purpose: Cyber Entrepreneurship is gaining much prominence in both developed nations and developing nations and has thus created higher demand for need to study cyber entrepreneurship.

In tandem, entrepreneurship and cyber entrepreneurship have been the focus of researchers, educators as well as public and private bodies'.
\end{abstract}

Methodology: The research methodology is based on case study method. This paper explores the initiatives in cyber entrepreneurship in various parts of the world through content analysis of journal articles and websites on the subject.

Findings: The findings of the research study show that cyber world has given birth to a new breed of cyber entrepreneurs who have used information technology and the Internet to create small, self-sustaining financial ecosystems using a minimum of financial and infrastructural resources creating employment for themselves and this new breed has created employment for others.

Originality/contribution: This paper contributed by identifying various practices adopted by successful cyber entrepreneurial ventures.

Key words: Entrepreneurship, Internet entrepreneurship, online entrepreneurship, Cyber entrepreneurship, Information technology.

\section{Council for Innovative Research}

Peer Review Research Publishing System

\section{Journal: International Journal of Management \& Information Technology}

Vol. 8, No. 1

editor@cirworld.com

www.cirworld.com, member.cirworld.com 


\section{INTRODUCTION}

Entrepreneurship is getting wider attention with increasing globalization and also the recent downturn in the world economies. It is believed (the assumption) that entrepreneurship promotes economic growth. In fact, some claim that entrepreneurship is critical to sustain the economy and to achieve or maintain competitiveness (Matlay, 2005). Further the increasing development of information technologies (IT) has significantly affected both firms and markets. IT is currently changing the world in a more permanent and far-reaching way than any other technology in the history of mankind (Carrier, Raymond \& Eltaief, 2004). It has become a widely-recognized fact that entrepreneurs and information technology have become the backbone of the world economy.

Information technology promotes a new form of entrepreneurship: cyber-entrepreneurship. Cyber entrepreneurship is a new source of economic growth and development Cyber-entrepreneurshipis extended version of entrepreneurship which cyber is a new method of doing business. The cyber entrepreneurship is using information technology as a platform and purely on internet platform (Badaruddin, Arokiasamy, Nordin, Yusof, and Zakaria, 2012). It is still in an emerging phase and the entrepreneurial process of opportunity exploration and exploitation (Shane and Venkataraman, 2000) is not well understood; it's an understudied phenomenon. Thus cyber entrepreneur development is one of the fundamental solutions to the economic development and globalization. Specially, developing necessary resources in developing cyber entrepreneurs which tend to have great impact on economies growth. The structure of the paper is as follows.

Entrepreneurship has long been considered an important economic activity. The past 20 years has witnessed an explosion of research into entrepreneurs and their actions (Venkataraman, 1997; Hannafey, 2003) with considerable emphasis on the elements that constitute successful entrepreneurship. There is no doubt that entrepreneurship has tremendous impact on the economy and on society. In 2004, a report by the Global Entrepreneurship Monitor (GEM) stated that a considerably large number of people are engaged in entrepreneurial endeavors around the world. Based on a sample of 34 countries representing a total labor force of 566 million people, GEM research estimates that 73 million adults are entrepreneurial (Acs, Arenius, Hay, \& Minniti, 2005). Therefore, there is a need to study the cyber entrepreneurial practices for enhancing economic development. The structure of the paper is as follows. A detailed literature review has been done and followed by it, we have studied the national and international cyber entrepreneurial ventures through cases, namely, Amazon.com, eBay.com, Flipkart, and snapdeal.com. Implications for research and practices are also discussed.

\section{LITERATURE REVIEW}

E-business is described as Internet-facilitated integration of business processes, applications, and Information systems (Tiwana and McLean, 2001). However, Reedy etal. (2000) defined e-business as any business carried out over an electronic network exchanging data files, having a website and doing online transactions with customers or suppliers. Internet-based electronic business (e-business), which refers to conducting value chain activities (including sales, customer services, procurement, information sharing and coordination with suppliers) by using the Internet platform (e.g., TCP/IP, HTTP, XML) in conjunction with existing information technology (IT) infrastructure (Zhu and Kraemer 2005). As exemplars of success, traditional firms such as Dell, Cisco, General Electric, Wal-Mart, and Charles Schwab, along with firms "born on the Internet/' like Amazon and eBay, have shown the potential of ebusiness to enhance customer services, streamline internal operations, and improve inter firm coordination (Straub et al. 2002). Fichman (2000) defines e-business assimilation as a series of stages from a firm's initial evaluation of ebusiness at the pre adoption stage (initiation), to its formal adoption, and finally to its full scale deployment at the post adoption stage in which e-business becomes an integral part of the value chain activities (routinization).

Entrepreneurship is a process integrating opportunity, resources and people the entrepreneurs (Timmons \& Spinelli, 2009). Gartner (1988) states that the entrepreneurs are individuals with have a specific set of personality explain a person as an entrepreneur. Personality traits have proven to be predictors of many aspects of entrepreneurship including the intention to start a business, succeed in running a business, and enhance corporate entrepreneurship (Shaver and Scott, 1991). The recent expansion and growth in the business world and the word "entrepreneurship" gained new paradigm and change the world economy. There are quite a few definitions of entrepreneurship, but in its qualities, it is a dynamic process of vision, change and creation (Ahmed, Hafiz, Kashif and Nadeem, 2010). In the wider definition entrepreneurship is the novel business enterprise formation and entrepreneurial deed in creating business-enterprise (Shane and Venkataraman, 2000). It requires the entrepreneurs to idea generation, innovative, and creative ideas to accomplish both profit and success. Relation to profit and success, business becomes more competitive and limited customer. According to Gatewood et. al. (1995) the venture creation process is defined as "the process that takes place between the intention to start a business and making the first sale". The concept of entrepreneurship draws on economic theory that argues that the entrepreneur "shifts economic resources out of an area of lower and into an area of higher productivity and greater yield" (Drucker, 1985).

Entrepreneur', derived from the French word 'entreprendre', has at its root a concept of 'between-taker or gobetween'. Kuratko and Hodgetts (2004) describe an entrepreneur as a creator of new venture who faces uncertainty 
in many ways. They are individuals who have the capability to foresee opportunities, gather the needed resources time, energy, and money - and take actions necessary to ensure success (Geoffrey, Robert and Philip, 1982; Moorman and Halloran, 1993; Meredith, Nelson and Neck, 1982).

Schumpeter (1934) defines an entrepreneurship as a company that undertakes a new arrangement to produce new products and services. Brockhaus (1976) defines the term as activities related to a firm's ownership and management, while Hisrich (2004) relates it to a dynamic process of wealth creation that requires individuals to sacrifice their time, show their commitment, and bear the financial, physiological and social risks in order to gain benefits in terms of monetary and personal satisfaction. Entrepreneurship has recently viewed as a process of innovation and creation with four dimensional elements - individual, organization, environmental factors, and process, with support from the government, education, and constitution (Kuratko and Hodgetts, 2004).Gartner (1988) states that the entrepreneurs are individuals with have a specific set of personality explain a person as an entrepreneur. Personality traits have proven to be predictors of many aspects of entrepreneurship including the intention to start a business, succeed in running a business, and enhance corporate entrepreneurship (Shaver and Scott, 1991). The term entrepreneur first appeared in the French language; but Richard Cantillion (1755) (Cited by Grebel et al., 2003), an Irishman living in France, was the first to use the term "entrepreneur". He viewed the entrepreneur as one who buys factors of production at certain prices and sells his product at uncertain prices, thereby bearing a non insurable risk that may arise due to depressed demand for his product. Say (1803) considered entrepreneur as one who performs the functions of rationally combining, co-ordinating and supervising various factors of production. According to Knight (1921), entrepreneurs are a specialized group of people who bear risks and deal with uncertainty. Smith (1776)(cited by Singh, 1993), the father of political economy, considered entrepreneur as a proprietary capitalist, a supplier of capital at the same time working as manager between labour and consumer. Schumpeter (1951) described an entrepreneur as "an innovator, one who brings about change through introduction of new technological process or products." Thus, an entrepreneur refers to: a person who bears the non-insurable risk, works under uncertainty, combines and manages the factors of production, innovates on all fronts on regular basis, functions as proprietary capitalist and is motivated by profits. According to Gatewood et. al. (1995) the venture creation process is defined as "the process that takes place between the intention to start a business and making the first sale". Much of the research on process of venture creation has assumed a linear, unitary process, composed of a set of activities, beginning with the recognition of a business opportunity and culminating with the first sale (Galbraith, 1982; Kazanjian \& Drazin, 1990; Liao et. al., 2005; Shane \& Venkataraman, 2000; Webster, 1976).

\section{Cyber entrepreneurship}

Waddell, Singh, Musa (2006) in their paper have defined are four broad categories: the home-based entrepreneur, the serial entrepreneur, the traditional entrepreneur, and, more recently, the cyber entrepreneur. The first three categories are self explanatory, but the birth of the commercial Internet gave rise to the cyber entrepreneur, one who takes pride in the fact that they do not have a "bricks-and-mortar" operation. Cyber entrepreneurs transact all their business with customers, suppliers, strategic partners, and others on the Internet and deal in digital products and services that do not require bricks-and-mortar infrastructure like warehousing and physical distribution (Allen, 2003).

Cyber entrepreneurship is extended version of entrepreneurship which cyber is a new method of doing business. The cyber entrepreneurship is using information technology as a platform and purely on internet platform. According to Shane and Venkataraman (2000), individuals who are interested to innovate and exploit opportunities generated by the development of new information technologies are known as cyber entrepreneurs. Meanwhile, Mohd Nizam and Lawrence Arokiasamy (2010) defined cyber entrepreneurship or cyber entrepreneur "as any start -up business or any attempt to exploit the information technology for business purposes and intended to gain profit in return". Besides this, Christian (2009), defined cyber entrepreneur as an individual who creates a firm that is essentially found upon ecommerce, and whose main activities are based on the exploitation of networks, using internet, intranets and extranets. Dotcoms are generally created by Internet-based entrepreneurs, also called cyberentrepreneurs.

Matlay (2004) stated that e entrepreneurship or electronic /internet entrepreneur represent new company in the digital economy (neteconomy). According to Bret \& Champeaux (2000) a cyberentrepreneur creates a firm that is essentially founded upon electronic commerce, and whose main activities are based on the exploiting networks using Internet, intranets and extranets. Although entrepreneurship literature tends to focus more on what we called "traditional entrepreneurs", some researchers are beginning to examine new forms of entrepreneurship based upon technology, and more specifically Internet (Carrier, Raymond \& Eltaief, 2004; Colombo \& Delmastro, 2001; Fillis, Johannson \& Wagner, 2004; Hansen \& Bird, 1997; Kazanjain \& Drazin; 1990; Keeley \& Roure, 1990; Kisfalvi, 2002, Martin \& Wright, 2005 among others).

Internet entrepreneur -An internet entrepreneur is defined as an individual who develops a business based on the internet connectivity model (i.e. IP based protocol) and strategically manages new business models and technologies by implementing product, service, process and/or knowledge innovation for fast growth outcomes (see Wong, 2008; Millman et al., 2009). 
Cyber entrepreneurship is still in its emergent phase, and there is more to know about the phenomenon and the elements of the venture creation process (Carrier et. al., 2005; Jiwa et. al., 2004; Martin \& Wright, 2005).Dotcoms are generally created by Internet-based entrepreneurs, also called cyber entrepreneurs.. Although entrepreneurship literature tends to focus more on what we called "traditional entrepreneurs", some researchers are beginning to examine new forms of entrepreneurship based upon technology, and more specifically Internet (Carrier, Raymond \& Eltaief, 2004; Colombo \& Delmastro, 2001; Fillis, Johannson \& Wagner, 2004; Hansen \& Bird, 1997; Kazanjain \& Drazin; 1990; Keeley \& Roure, 1990; Kisfalvi, 2002, Martin \& Wright, 2005 among others).

\section{CASELETS ON CYBER ENTREPRENEURIAL VENTURES}

With the increased usage of Internet and awareness among the consumers the E-commerce websites are gaining importance .In fact there are lot of young entrepreneurs who have successfully launched online business and are doing exceptionally well.

\section{Amazon.com}

Amazon world's largest online retailer, was started by Jeffrey who came up with an idea that changed his life, and of everyone around him. In the mid-1990s, when other entrepreneurs were trying to figure out how to use the internet to make a buck, Jeff Bezos already had a pretty good vision of what was to come. And here's what he saw: a really big shopping mall. Jeffrey quit his cushy, well-paid job at a New York hedge fund to start an online bookstore called Cadabra in his garage. Imagine how people must have looked at him on idea of Online bookstore then. Today, Cadabra is a company worth 90 billion dollars. Jeffrey is one of the richest people in the world, his personal wealth estimated to be about 22 billion dollars. That's just an estimate. The guy is now known as Jeff Bezos. And Cadabra is Amazon. Factors beyond Amazon.com global acceptance and success can be categorized into 4 categories: offering competitive prices, straightforward web design and friendly interface, convenient payment system, and most importantly the unique shopping experience. Amazon first ventured beyond books when it added music and DVDs in 1998. Electronics, toys, games, home improvement items, software and video games came a year later. Today it has 31 product categories and does business in seven countries. Amazon.com began selling stock publicly in 1997. Bezos, of course, scored big. He's now worth around $\$ 7$ billion.

\section{eBay.com}

eBay is the one of the world's premier online properties and the corporate home of a number of successful Internet brands. With nearly 100 million active users, eBay's core marketplace site hosts millions of retail and wholesale transactions in some 30 countries every day. eBay, Inc. employs some 17,700 workers around the world. Founded in 1995 by 28-year-old Internet entrepreneur and current Chairman Pierre Omidyar. He demonstrated skillfulness in both realms by creating eBay, the online auction site that's driven his wealth to more than $\$ 3.6$ billion. eBay was taken public in 1998 and today enjoys a market capitalization of approximately $\$ 40$ billion. Computer programmers are often known more for their coding capabilities than their business expertise. Pierre Omidyar happens to understand a lot about both .In 1995, the French-born Iranian (who now resides in Hawaii) wrote Web code that let him put a laser pointer up for auction online. He didn't expect the item to actually sell, but when it did, Omidyar realized that the Internet auction concept might work.

\section{Flipkart.com}

Flipkart.com is one of India's largest online bookstores, offering various products ranging from fashion to fitness, accessories, and gadgets from electronics to home and lifestyle. The secret being the popularity of Flipkart.com are attractive prices and great delivery service. Flipkart was established by Sachin Bansal and Binny Bansal. The two Alumni of the IIT Delhi commenced the project in 2007 after quitting Amazon.com. A firm that the Bansals started by funding themselves with just Rs. 400,000 now has strength of 4500 employees. The entrepreneurship generated revenue of Rs. 500 crore during $2011 \neg-12$.From a start-up with an investment of just four lakhs rupees, Flipkart has grown into a $\$ 100$ million-revenue online retail giant in just five years.

\section{Snapdeal.com}

Snapdeal.com founded by Wharton graduate Kunal Bahl and IIT Delhi alumnus Rohit Bansal in February 2010, the daily deal website has grown to become one of the largest Indian eCommerce websites shipping more than 25000 products daily. The online retail chain offers a wide range of products from electronics, clothing, accessories, furnishing to sports and fitness products. The daily deal website comes up with attractive discounts and deals over a wide variety of retailed products almost every day. With 20 million registered users, SnapDeal is one of the first and largest online marketplace in India offering an assortment of 4 million+ products across diverse categories from over 20,000 sellers, shipping to 4000 towns and cities in India.

Snap Deal has gone on to become a huge brand where the deals have a good validity period and are customized for the Indian way of spending. As of now, it is networked in six cities and has a 15-city plan coming up soon. 


\section{SYNTHESIS OF LEARNING ISSUES}

The secondary data collected has been analyzed and interpreted in the context of cyber entrepreneurship. The learning issues from this case study are as follows:

The literature survey of successful cases of cyber entrepreneurship provides some basic frameworks and insights with regard to the diversity of initiatives taken in the cyber world by entrepreneurs to promote business. The emerging practices in Cyber entrepreneurship are running in different phases in the countries analyzed. For instance, firstly, US based internet entrepreneurs launched the online business in early 1990's however in case of Indian cyber entrepreneurs the ventures have gained momentum only after 2005 . And cyber entrepreneurship in India is in a very nascent stage, however growing at a tremendous rate and there is a lot of potential that can be developed in this area.

Further as seen in the four cases in today's highly networked world, a cyber entrepreneur does not need to invest huge money, he only needs to invest his intellect and explore his connections and capabilities in the cyber world. The individual's utility from any particular job including cyber entrepreneurship depends not only on income but also on the interest and working conditions such as decision making control, risk exposure, work effort, etc.

The initiatives above demonstrate human capacity development and entrepreneurship promotion are central issues in bridging the digital divide. Majority of recent publications of International Organizations stress the fact that the encouragement and support of e-entrepreneurship is indispensable if developing countries don't want to miss out on the possibilities of ICT.

\section{RESEARCH IMPLICATIONS}

There is a need to study priority of Cyber entrepreneurship as an engine of growth and thus pursue policies deemed to promote cyber entrepreneurial activities especially through education and training.

\section{CONCLUSION AND DISCUSSION}

Four cases of Cyber Entrepreneurial ventures have been discussed and the synthesis of learning issues has been presented. The source of information was various journals articles and websites. The major limitation of the study was that the cases have been selected on the basis of purposive sampling. The study has been carried out for limited number of Cyber entrepreneurial ventures. Only these Cyber entrepreneurial ventures may not be true representative of the Cyber Entrepreneurial success or practices undertaken by firms. However, the study has projected the success of cyber entrepreneurial ventures and the need to further investigate and find out the determinants and drivers of cyber entrepreneurship and can form the basis of further empirical study.

Cyber entrepreneurial interest is a term used to describe the readiness and willingness to become an internet-based self-entrepreneur. With an increase in number of students graduating, opting cyber entrepreneurship as a career is essential not only to reduce unemployment rate but it can also provide additional source of income in line with an increasing cost of living.

Entrepreneurship plays a particularly critical role during periods of rapid economic change, as small, agile firms increase the ability of an economy to quickly respond to new challenges. In the current state of economy there is a need to look beyond traditional means of employment creation. One way of looking at it would be to create employers instead of employees, possibly by focusing more on creating self-employment opportunities as it is clearly seen in the above cases of cyber entrepreneurial ventures. In the present context, information technology offers a unique way of creating a possible solution to achieve low cost platform for business execution. It is possible to use information technology and the Internet to create small, self-sustaining financial eco-systems using a minimum of financial and infrastructural resources.

Unfortunately, most developing countries have a poor environment for stimulating cyber entrepreneurship. In general, there is a lack of knowledge and policy guidelines with respect to the new business models that characterize internetcentered businesses. People that combine skills and creativity in Internet site creation, business know-how, access to finance and knowledge of local community needs are still relatively rare worldwide, but particularly in developing countries. Nevertheless, digital opportunity initiatives are far from inevitable and having right policies and practical actions, ICT can be a powerful enabler of development of Cyber entrepreneurship which further can substantially improve the burden on public resources being used to create employment opportunities for the unemployed. The model of cyber entrepreneurship can also facilitate the employment opportunities with least investment model for providing financial inclusion to the people.

\section{REFERENCES}


[1] Millman, C., Li, Z., Matlay, H., Wong ,W. ,2010) Entrepreneurship Education And Students' Internet Entrepreneurship Intentions Evidence from Chinese HEls, Journal Of Small Business And Enterprise Development Vol. 17 no. 4, 2010 Pp. 569-590.

[2] Arthur, S. J., Hisrich ,R.D, Cabrera ,A.,(2012) The Importance Of Education In The entrepreneurial process: a world view, Journal of small business and Enterprise development Vol. 19 no. 3, 2012 Pp. 500-514.

[3] Fusilier, M., Durlabhji,S. (2003) No Downturn Here: Tracking E-Business Programs in higher Education, Decision Sciences Journal Of Innovative Education Volume 1 number 1 spring 2003 Printed in the U.S.A.

[4] Watkins, T.A., Russo, M.J., Ochs, J.B. (2008) Can students in technology Entrepreneurship courses help Foster start-ups by the Unemployed?, Journal of Small Business and Enterprise Development, Vol. 15 no. 2, pp. 348-364.

[5] Zhu,K., Kraemer, K,L., XU, S. (2006) The Process Of Innovation Assimilation By Firms In Different Countries: A Technology Diffusion Perspective On E-Business, Management Science, Vol. 52, No. 10 , pp. 1557-1576.

[6] Rae,D.,(2010) Universities And Enterprise Education: Responding To The Challenges Of The New Era ,Journal Of Small Business And Enterprise Development Vol. 17 No. 4, 2010 pp. 591-606.

[7] Solesvik,M,Z., Westhead,P., Kolvereid,I., Matlay,H.(2012) Student Intentions To Become Self-Employed:The Ukrainian Context ,Journal Of Small Business And Enterprise Development Vol. 19 No. 3, 2012 Pp. 441 460.

[8] Hamidi, D.Y., Wennberg ,K., Berglund ,H.(2008) Creativity In Entrepreneurship Education, Journal Of Small Business And Enterprise Development Vol. 15 No. 2, 2008 pp. 304-320.

[9] Sowmya,D., V., Majumdar ,S.,(2010) Relevance Of Education For Potential Entrepreneurs: An International Investigation, Journal Of Small Business And Enterprise Development Vol. 17 No. 4, 2010 pp. 626-640.

[10] Matlay,H.,(2008) The Impact Of Entrepreneurship Education On Entrepreneurial Outcomes, Journal Of Small Business And Enterprise Development Vol. 15 No. 2, pp. 382-396.

[11] Jones,C.,(2010) Entrepreneurship Education: Revisiting Our Role And Its Purpose, Journal Of Small Business And Enterprise Development Vol. 17 No. 4, 2010 pp. 500-513.

[12] Bock, A. J., \& George, G. (2011) The Business Model In Practice And Its Implications For Entrepreneurship Research, Entrepreneurship Theory And Practice, 35(1), 83-111, Doi: 10.1111/J.1540-6520.2010.00424.X.

[13] Badaruddin, Mohd ,B.A., Arokiasamy,L., Nordin ,N. M., Yusof ,H.,, Zakaria ,T. (2012) Cyber-Entrepreneurial Intention Among Business Undergraduates In Institutions Of Higher Learning In Malaysia, Proceeding Of 2nd International Conference On Management ISBN: 978-967-5705-07-6.

[14] Avgerou ,C., \& Li ,B. (2012) Relational And Institutional Embeddedness Of Web-Enabled Entrepreneurial Networks: Case Studies Of Netrepreneurs In China, Info Systems J (2013) Doi:10.1111/isj.12012.

[15] Piperopoulos ,P.,(2012) Could Higher Education Programmes, Culture And Structure Stifle The Entrepreneurial Intentions Of Students? , Journal Of Small Business And Enterprise Development Vol. 19 No. 3, 2012 pp. 461-483.

[16] Stace, D., Holtham ,C., Courtney,N. (2001) E-Change: Charting A Path Towards Sustainable E-Strategies, Strategic Change, Volume 10, pp.403-418.

[17] Klapper ,R., Tegtmeier,S., (2010) Innovating Entrepreneurial Pedagogy: examples from France and Germany ,Journal Of Small Business And Enterprise Development Vol. 17 no. 4, 2010 pp. 552-568.

[18] Ismail, Mohammad., Khalid,S.A., Othman , Mahmod., Jusoff ,H.K., Rahman,N.A., Kassim ,K. Mohamed., Zain ,R.S. (2009) Entrepreneurial Intention Among Malaysian Undergraduates , International Journal Of Business And Management, Vol. 4 ,No 10,2010 pp.54-60.

[19] Wang1,W., Lu ,W., Millington,J.K. (2011) Determinants of Entrepreneurial intention Among college students in China and USA, Journal Of Global Entrepreneurship Research, Winter \& Spring, 2011, vol.1, no.1, pp.3544.

[20] Sahay,A., Rai ,S.K. (2004) How Entrepreneurial Are Youth Of Varanasi: An Empirical Study Through Cyber Café's, Journal Of Services Research, Volume 4, Number 2.

[21] Foster ,J., Lin,A. (2003) Individual Differences In Learning Entrepreneurship And Their Implications For Web-Based Instruction In E-Business And E-Commerce, British Journal Of Educational Technology Vol 34 No 4 ,pp455-465.

[22] Dickson, P.H., Solomon,G.T., Weaver,K.M. (2008) Entrepreneurial Selection And Success: Does Education Matter? , Journal Of Small Business And Enterprise Development Vol. 15 No. 2, 2008 pp. 239-258.

[23] Wong, X., Yen,D.C., and Fang,X. (2004),E-Commerce Development In China And Its Implication For Business Asia Pacific Journal Of Marketing And Logistics Volume 16 Number 3.

[24] http://daily.bhaskar.com/article/MON-sucess-stories-of-indias-five-fastest-growing-electronic-commercewebsites-4371919-PHO.html

[25] http://ebay.about.com/od/gettingstarted/a/gs whatisebay.htm

[26] http://www.biography.com/people/jeff-bezos-9542209

[27] http://www.businessinsider.com/why-amazon-is-so-hugely-successful-2012-12?IR=T

[28] http://blog.freshdesk.com/amazons-customer-happiness-story/

[29] http://www.rockying.com/a/64 
[30] http://ebay.about.com/od/ebaylifestyle/a/el history.htm

[31] http://en.wikipedia.org/wiki/Snapdeal

\section{Author' biography with Photo}

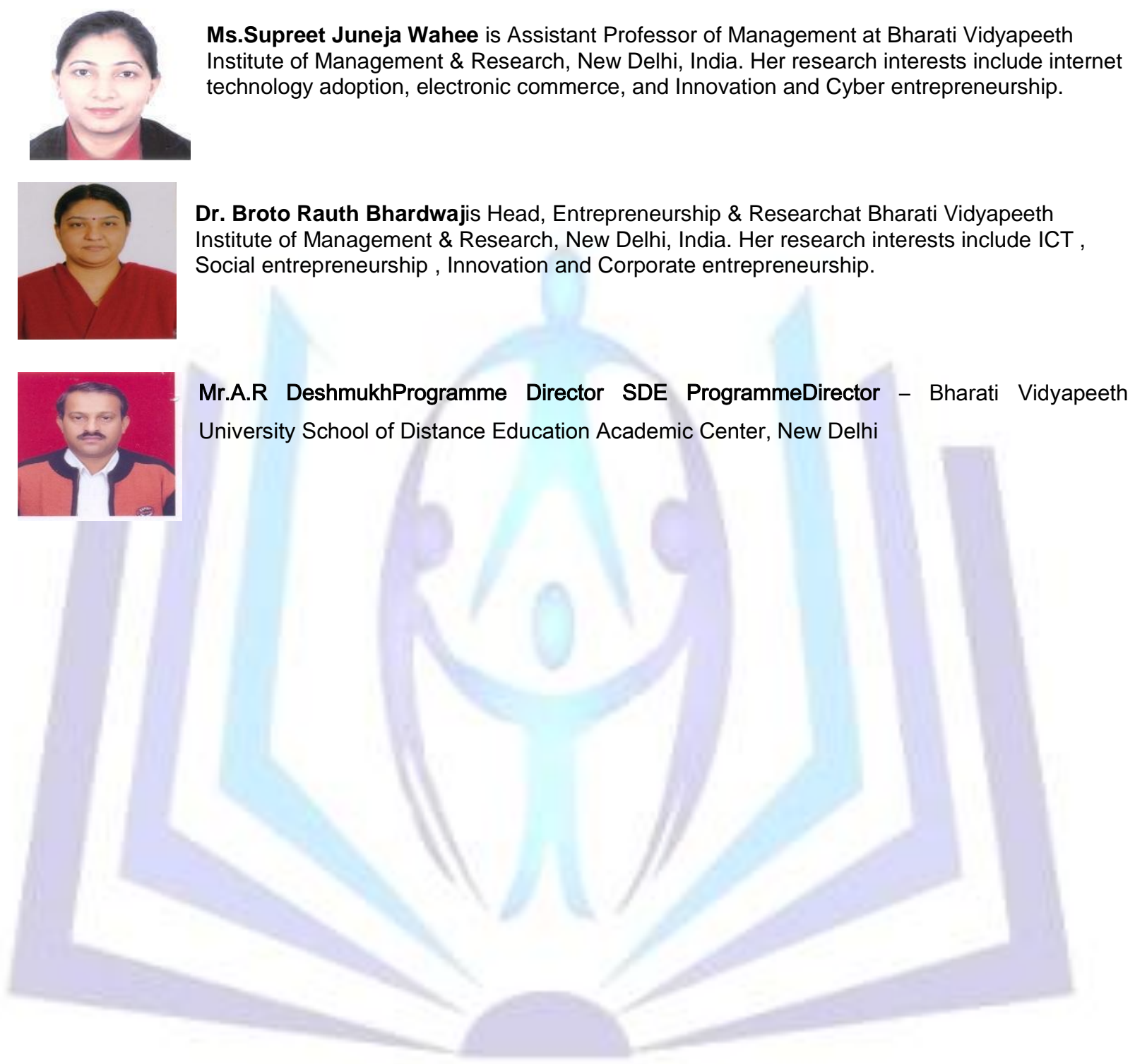

